\title{
The Contributions of Physiologic Birth and Cesarean Delivery to Attachment and Social Skills of 6-Year-Old Children
}

\author{
Serdal SEVEN¹, Melek AŞIK² , Fatma Nur SAYLAĞ ${ }^{3}$
}

\section{ARTICLE INFO \\ Article History: \\ Received 09.09.2019 \\ Received in revised form \\ 02.05.2020 \\ Accepted \\ Available online 01.07.2020}

\begin{abstract}
The aim of the current study is to investigate the contributions of physiologic birth and cesarean delivery to attachment and social skills of 6-year-old children. A causal-comparative research design was employed. The study was conducted during the Fall of 2017 and Spring of 2018 in 2 low SES state preschools randomly-selected in Bağclar District, in İstanbul. The sample of the study is made up of a total of 50 children (23 girls and 27 boys). 20 of the children were normally delivered whereas 30 of them were cesarean born. Incomplete Stories with a Doll Family (ISDF) and Social Skills Rating System (SSRS) were used for the data collection. A t-test and One-Way ANOVA were employed for the data analysis. The results showed that that attachment levels and social skills of 5- and 6 year-old children differed significantly by types of child delivery favoring normally born children.
\end{abstract}

C IJERE. All rights reserved

Keywords:

Cesarean Delivery, attachment, social skills, preschool

\section{INTRODUCTION}

Several biological mechanisms that are activated during vaginal child delivery seem to influence attachment (Sayıner and Özerdoğan, 2009). Keverne, Levy, Poindron, and Lindsay, (1983) discovered the mechanism of vaginal-cervical stimulation in lamb, which also helps babies recognize their mothers.

Secretion of oxytocin is another important mechanism. Takeda, Kuwabara, and Mizuno, (1985) found that oxytocin level increases during and after delivery in mothers' brain, specifically in spinal fluid. Oxytocin during pregnancy and during the post-natal period is associated with mothers' attachment to infants (Campbell, 2008; Feldman, 2012; Galbally, Lewis, Ijzendoorn, and Permezel, 2011). During the hours following birth, the secretion of oxytocin triggers nurturing feelings and behavior (Güleşen and Yıldız, 2013). However, cesarean delivery has been associated with lower levels of oxytocin (Nissen et al., 1996), which may result in a less secure mother-infant attachment (Galbally et al., 2011).

Cortisol is another hormone that has been associated with mother-infant attachment. Cortisol increases during delivery, which is a sign of the development of maternal attachment (Fleming, Steiner, and Corter, 1997). Cesarean delivery is also associated with low levels of cortisol (Vogl et al., 2006), which may result in a less secure mother-infant attachment. Mothers go through many biological changes not only during pregnancy but also after delivery. Noradrenaline is one of the first hormones that is released during delivery. It increases during uterine contractions. When children are born, the first thing they smell is maternal odor, which is known to play an important role in child-mother attachment. Noradrenaline helps newborns recognize maternal body odor. Cesarean children are less likely to attach maternal odor as they do not experience uterine contractions and noradrenaline stays low during cesarean delivery (Varendi, Porter, and Winberg, 2002).

Attachment during early years is related to relationships later in life (Seven, 2008; Seven and Ogelman, 2012). Forming healthy relationships depends on secure parent-infant attachment in the early years. The social interactions of mother and child contributes to the development of child's social skills. Children forming secure bonds with their caregivers tend to develop more positive behavior and play more active roles in social relationships compared to children with insecure attachment styles (Seven and Alabay, 2020).

The formation of secure parent-infant attachment is fundamental to social and emotional development of children (Seven, 2010). Secure attachment contributes to children's peer relations, problem solving skills, self-image and self-control in a positive way (Cassidy, 1988). Previous research on secure and insecure attachment points out that children securely attached to their caregivers are more interactive in peer relationships and more competent in social skills demonstrating more prosocial behavior (Güleç and Kavlak, 2013; Seven, 2008; Seven and Ogelman, 2012).

\footnotetext{
${ }^{1}$ Corresponding e-mail:sseven@fsm.edu.tr_.Fatih Sultan Mehmet Vakıf Üniversitesi , orcid.org/0000-0003-3965-4725 
Although there are many studies focusing the association between child delivery and social skills (Ebrahimi, Karimian, Kolahdozan, and Emamian, 2020; Gathwala and Narayanan, 1991; Korja, Latva, and Lehtonen, 2012; Mutryn, 1993; Zanardo et al., 2016), the number of studies investigating the contributions of types of child delivery to attachment and social skills seems insufficient. Therefore, the following research questions will be addressed within the scope of the present study:

1. Does attachment differ by types of child delivery?

2. Do social skills differ by types of child delivery?

3. Do assertion, cooperation and self-control skills differ by types of child delivery?

\section{METHOD}

\section{Research Design}

A causal-comparative research design was employed. In addition to the descriptive methods, comparison of groups is required. Researcher focuses on a variable in its natural settings and tries to identify the underlying factors of its difference (Başol, 2008).

\section{Participants}

The study was conducted during the Fall of 2017 and Spring of 2018 in 2 low SES preschools randomlyselected in Bağcllar District, in İstanbul. All the children aged 60-72 months in 4 classes participated in the study. The sample of the study is made up of a total of 50 children ( 23 girls and 27 boys). 20 of the children were normally delivered whereas 30 of them were cesarean born.

\section{Material}

Social Skill Rating System Teacher Form -SSRS

Teacher Form was used to collect social skills data. The Social Skills scale, as a measurement area of SSRS-TF, has three subscales, which are Assertion, Cooperation and Self-Control. The Problem Behaviors Scale includes two subscales, which are Externalizing Problems and Internalizing Problems. These two scales have a total of 48 items. The scores are interpreted as low, medium or high level of social skills.

The Social Skill Rating System was developed by Gresham and Elliott (1990). An analysis of internal consistency yielded average coefficient alpha reliabilities (across all forms and educational levels) of .90. Test-retest reliability scores correlated .85 (Oprea, 1998). The scale was adapted to Turkish by Seven (2006). The validity was tested with Exploratory Factor Analysis, $t$-test and Confirmatory Factor Analysis. The results showed that the scale has a three-factor structure. The results yielded coefficient alpha reliabilities of .94 for the Social Skills scale, .93 for the Cooperation subscale, .86 for the Self-Control scale, and .83 for the Assertion scale. "Quickly make friends." is the one of sample item.

Incomplete Stories with Doll Family

It was developed by Cassidy (1988) for children at the age of six. It is administered with a doll telling six stories, each of which lasts about three minutes, relevant to her family. Children are expected to talk about their mental representation about their attachment state through these stories, which gives clues about the child's attachment to his/her mother.

During the assessment, dolls and dollhouse are arranged in line with the stories. Then, the child is asked to imagine himself as if living in the dollhouse and choose a doll to represent himself. The child is allowed to play with the dolls for some time to explore them before the administration.

Each story is rated by coders who do not know the child from verbatim on a five-point scale. High scores are given to the stories which represent the child's secure attachment to the attachment figure. Each story is rated by coders separately. "Puppet interviews", "Harter's Scale of Perceived Competence and Social Acceptance for Young Children" and "self interview" were used to test the reliability and validity of the tool and consistency ranged between .47-.68 (Cassidy, 1988). The reliability Alpha coefficient was .78 and the testretest coefficient was .63. The scale was adapted to Turkish by Seven (2006) and the Cronbach's Alpha coefficient was .94 for the Turkish version.

\section{Demographics Form}

It aims to collect demographic data from the participating children and parents, including types of delivery, gender, date of birth, and maternal education. It was completed by parents. 


\section{Data Analyses}

Incomplete Stories with a Doll Family (ISDF) and Social Skills Rating System (SSRS) were used for the data collection. ANOVA and t-test were employed for the data analysis. SSRS were completed by the teachers and ISDF were administered by the researchers during the interviews with the children.

\section{FINDINGS}

As seen in Table 1, \%40 of the children were born normally while \%60 of the children were cesarean. $\% 56$ of the children were boys and \%44 were girls. \%68 of the children were born in 2012 and \%32 were born in 2013.

Table 1. Child Demographics

\begin{tabular}{cccc}
\hline Variables & Grup & N & \% \\
\hline Type of & Normal & 20 & 40 \\
\cline { 2 - 4 } Child Delivery & Ceserean & 30 & 60 \\
\hline Gender & Male & 28 & 56 \\
\cline { 2 - 4 } & Female & 22 & 44 \\
\hline Birth year & 2012 & 34 & 68 \\
\cline { 2 - 4 } & 2013 & 16 & 32 \\
\hline
\end{tabular}

Table 2 shows that attachment styles seem to differ by types of child delivery for 5 - and 6 year-old children $\left[t_{(48)}=3,92, p>.001\right]$. Normally born children $(\bar{X}=23,7)$ had higher levels of attachment than cesarean children $(\overline{\mathrm{X}}=19,6)$.

Table 2. T Test Results Comparing Types of Birth on Attachment

\begin{tabular}{cccccc}
\hline Gender & $\mathbf{N}$ & $\bar{x}$ & sd & $\mathbf{t}$ & $\mathbf{P}$ \\
\hline Normal & 20 & 23,7 & 48 & 3,92 & 0.00 \\
Cesarean & 30 & 19.6 & 47,9 & \\
\hline
\end{tabular}

Table 3 shows that social skills of 5 - and 6 year-old children seem to differ by types of child delivery ( $\mathrm{F}$ $=5,65, p>.05)$. Normally born children $(\bar{X}=43,6500)$ had scored higher than cesarean children $(\bar{X}=35,2000)$ in social skills. Similarly, normally born children $(\bar{X}=18,70 ; 9,85)$ scored higher than cesarean children $(\bar{X}$ $=14,46 ; 9,16)$ in the Assertion and Self-Control Subscales $(F=6,60, p>.05 ; F=8,05, p>.05)$. However, there was no significant difference between the groups in Cooperation Subscale $(\mathrm{F}=1,52, \mathrm{p}<.05)$.

Table 3. Mean Scores for Social Skills Subscales by Types of Child Delivery and ANOVA Results

\begin{tabular}{|c|c|c|c|c|c|c|}
\hline Factor & $\begin{array}{c}\text { Types } \\
\text { Of Child } \\
\text { Delivery }\end{array}$ & $\mathbf{N}$ & $\bar{X}$ & $\begin{array}{r}\text { Standard } \\
\text { Error }\end{array}$ & $\mathbf{F}$ & Sig \\
\hline \multirow[t]{2}{*}{ Assertion } & Normal & 20 & 18,70 & 2,451 & $\begin{array}{r}6,6 \\
0\end{array}$ & ,013 \\
\hline & Cesarean & 30 & 14,46 & 4,336 & & \\
\hline \multirow[t]{2}{*}{ Cooperation } & Normal & 20 & 15,10 & 2,971 & $\begin{array}{r}1,5 \\
2\end{array}$ & ,24 \\
\hline & Cesarean & 30 & 11,56 & 3,568 & & \\
\hline \multirow[t]{2}{*}{ Self-Control } & Normal & 20 & 9,85 & 1,954 & $\begin{array}{r}8,0 \\
5\end{array}$ & ,71 \\
\hline & Cesarean & 30 & 9,16 & 3,974 & & \\
\hline \multirow[t]{2}{*}{ Social Skills } & Normal & 20 & 43,65 & 6,507 & & \\
\hline & Cesarean & 30 & 35,20 & 9,757 & $\begin{array}{r}5,6 \\
5 \\
\end{array}$ & 021 \\
\hline
\end{tabular}




\section{RESULT, DISCUSSION, AND SUGGESTIONS}

The results of the current study indicated that level of attachment seem to differ by the types of child delivery. Normally born children had higher levels of attachment than cesarean children, which was consistent with the previous research findings (Ebrahimi et al., 2020; Zanardo et al., 2016; Zavardehi, Faramarzi and Mirzaeian, 2018). Zavardehi, Faramarzi and Mirzaeian, (2018). Iranian children born in cesarean section were found to have less attachment compared to normally born children, which was further supported by Ebrahimi et al.,(2020). Similar findings were also obtained in Western studies. Zanardo et al., (2016) worked with Italian children and found that normally born children had higher levels of attachment to their mothers although the findings were limited to low SES children.

The results also showed that 6-year-old children's social skills differed significantly by the types of child delivery on behalf of normally born children. There are no studies focusing on the direct relationship between types of child delivery and social skills. Mutryn, (1993) investigated the psychosocial traits of normally born and cesarean children and suggested that cesarean children seem to have some disadvantages. There is an extensive body of literature suggesting that insecurely attached children tend to have weaker social skills (Gallarin and Alonso-Arbiol, 2012; Seven, 2006; Seven and Ogelman, 2012). As cesarean children are more likely to be insecurely attached to their caregivers, they are expected to be less competent in social skills.

Assertion, as a part of social skills, differed by types of child delivery favoring normally born children. However, no significant difference was found in Self-Control and Cooperation Subscales. Self-control and cooperation skills have a nature that may be supported by family and school during early years and preschool period. Wiklund, Edman, Larsson and Andolf, (2006) regarded assertion as a personal trait and found no significant difference by types of child delivery. The findings of the current study may be associated with SES of the parents. Lareau, (2011) observed that low-SES parents were more assertive in their interactions with their children. This is in line with the present study whose participants were all from low-SES households.

The present study is a prominent one as it investigates the links between types of child delivery, attachment and social skills. The results suggesting that attachment, which is related to many psychological concepts, do differ by types of child delivery underlines a social responsibility. This research has some limitations. The most important limitation of this research is that it is done with families with low socioeconomic level. Attachment and social skills of children form mid- and high-SES households may be investigated in future research. Another limitation of this research is that attachment is measured at 6 years of age. As the current study is limited to 6-year-olds, future research may focus on a wider age range. More research on the psychosocial effects of cesarean section specific to Turkish samples is needed. In future studies, it is recommended to repeat the study with younger children.

\section{REFERENCES}

Başol, G. (2008). Bilimsel araştırma süreci ve yöntem. In O. Kılıç \& M. Cinoğlu (Eds.), Bilimsel araştırma yöntemleri (pp. 113-143). İstanbul: Lisans Yayıncilik.

Campbell, A. (2008). Attachment, aggression and affiliation: The role of oxytocin in female social behavior. Biological Psychology. 77(1), 1-10. https://doi.org/10.1016/j.biopsycho.2007.09.001

Cassidy, J. (1988). Child-mother attachment and the self in six-year-olds. Child Development, 59(1), 121-134. https://doi.org/10.2307/1130394

Ebrahimi, E., Karimian, Z., Kolahdozan, S., \& Emamian, M. H. (2020). Attachment Behaviors in Physiological Birth Versus Cesarean Section. International Journal of Women's Health and Reproduction Sciences, 8(2), 215-220. https://doi.org/10.15296/ijwhr.2020.34

Feldman, R. (2012). Oxytocin and social affiliation in humans. Hormones and Behavior, Vol. 61. https://doi.org/10.1016/j.yhbeh.2012.01.008

Fleming, A. S., Steiner, M., \& Corter, C. (1997). Cortisol, hedonics, and maternal responsiveness in human mothers. Hormones and Behavior.32(2). 85-98. https://doi.org/10.1006/hbeh.1997.1407

Galbally, M., Lewis, A. J., Ijzendoorn, M. Van, \& Permezel, M. (2011). The role of oxytocin in mother-infant relations: A systematic review of human studies. Harvard Review of Psychiatry. 19(1), 1-14. 
Seven,S., Aș̣k,M. \& Saylağ,F.N. (2020). The contributions of physiologic birth and cesarean delivery to attachment and social skills of 6-year-old children.International Journal of Educational Research Review,5(3),208-213.

https://doi.org/10.3109/10673229.2011.549771

Gallarin, M., \& Alonso-Arbiol, I. (2012). Parenting practices, parental attachment and aggressiveness in adolescence: A predictive model. Journal of Adolescence, 35(6), 1601-1610. https://doi.org/10.1016/j.adolescence.2012.07.002

Gathwala, G., \& Narayanan, I. (1991). Influence of cesarean section on mother-baby interaction. Indian Pediatrics.28(1), 45-50.

Gülay H., D. M. S. S. (2011). Assessing the Relationship between Aggression Tendencies and the Secure Parental Attachment of Children going through Early Adolescence. World Applied Sciences Journal, 13(3), 203-409.

Güleç, D., \& Kavlak, O. (2013). Baba- bebek bağlanma ölçeğinin Türk toplumunda geçerlik ve güvenirliğinin incelenmesi. International Journal of Human Sciences.10(2), 170-181.

Güleşen, A., \& Yıldız, D. (2013). Erken Postpartum Dönemde Anne Bebek Bağlanmasının Kanıta Dayalı Uygulamalar ile İncelenmesi [Investigation of Maternal-Infant Attachment in The Early Postpartum Period With Evidence Based Practice]. TAF Preventive Medicine Bulletin Review TAF Prev Med Bull, 1212(22), 177-182. https://doi.org/10.5455/pmb1-1336130426

Keverne, E. B., Levy, F., Poindron, P., \& Lindsay, D. R. (1983). Vaginal stimulation: An important determinant of maternal bonding in sheep. Science, 219(4580), 81-83. https://doi.org/10.1126/science.6849123

Korja, R., Latva, R., \& Lehtonen, L. (2012). The effects of preterm birth on mother-infant interaction and attachment during the infant's first two years. Acta Obstetricia et Gynecologica Scandinavica. 91(2), 164-73 https://doi.org/10.1111/j.1600-0412.2011.01304.x

Lareau, A. (2011). Unequal childhoods: Class, race, and family life, with an update a decade later. In Unequal Childhoods: Class, Race, and Family Life, With an Update a Decade Later.

Mutryn, C. S. (1993). Psychosocial impact of cesarean section on the family: A literature review. Social Science and Medicine, 37(10), 1271-1281. https://doi.org/10.1016/0277-9536(93)90338-5

Nissen, E., Uvnäs-Moberg, K., Svensson, K., Stock, S., Widström, A. M., \& Winberg, J. (1996). Different patterns of oxytocin, prolactin but not cortisol release during breastfeeding in women delivered by Caesarean section or by the vaginal route. Early Human Development. 45(1-2) 103-18. doi: 10.1016/03783782(96)01725-2.

Oprea, L. M. (1998). The relationship of authoritative parenting style of Head Start families and the development of appropriate social skills in preschool children. Dissertation Abstracts International Section A: Humanities and Social Sciences.

Sayıner, F. D., \& Özerdoğan, N. (2009). Doğal Doğum. Maltepe Üniversitesi Hemşirelik Bilim ve Sanatı Dergisi, 2(3), 143-148.

Seven, S. (2006). 6 Yaş Çocuklarının Sosyal Beceri Düzeyleri ile Bağlanma Durumları Arasındaki İlişkilerin İncelenmesi. Gazi Üniversitesi.

Seven, S. (2008). Çocuk ruh sağhığı. Ankara: Pegem Akademi.

Seven, S. (2010). Attachment and social behaviors in the period of transition from preschool to first grade. Social Behavior and Personality: An International Journal, 38(3), 347-356. https://doi.org/10.2224/sbp.2010.38.3.347

Seven, S., \& Ogelman, H. G. (2012). Attachment Stability in Children Aged 6 to 9 Years in Extended and Nuclear Families. Early Education \& Development, 23(5), 766-780. https://doi.org/10.1080/10409289.2011.607362

Seven, Z. D., \& Alabay, E. (2020). Investigation of the interactions of mothers and their 30-42 months Old children who are living in different family types in the context of mother sensitivity. International Journal of Educational Research Review, 5(1), 70-82.

Takeda, S., Kuwabara, Y., \& Mizuno, M. (1985). Effects of pregnancy and labor on oxytocin levels in human plasma and cerebrospinal fluid. Endocrinologia Japonica, 32(6), 875-880. https://doi.org/https://doi.org/10.1507/endocrj1954.32.875

Varendi, H., Porter, R. H., \& Winberg, J. (2002). The effect of labor on olfactory exposure learning within the first postnatal hour. Behavioral Neuroscience, 116, 206-221. https://doi.org/10.1037/0735-7044.116.2.206

Vogl, S. E., Worda, C., Egarter, C., Bieglmayer, C., Szekeres, T., Huber, J., \& Husslein, P. (2006). Mode of delivery is associated with maternal and fetal endocrine stress response. BJOG: An International Journal 
of Obstetrics and Gynaecology, 113, 441-445. https://doi.org/10.1111/j.1471-0528.2006.00865.x

Wiklund, I., Edman, G., Larsson, C., \& Andolf, E. (2006). Personality and mode of delivery. Acta Obstetricia et Gynecologica Scandinavica, 85, 1225_1230. https://doi.org/10.1080/00016340600839833

Zanardo, V., Soldera, G., Volpe, F., Giliberti, L., Parotto, M., Giustardi, A., \& Straface, G. (2016). Influence of elective and emergency cesarean delivery on mother emotions and bonding. Early Human Development. 99, 17-20. doi: 10.1016/j.earlhumdev.2016.05.006.

Zavardehi, Z. P., Faramarzi, M., \& Mirzaeian, B. (2018). Quality of Mother - Infant Attachment after Physiological Birth. Int J Pediatr, 6(55), 7929-7936. https://doi.org/10.22038/ijp.2017.26765.2306 